\title{
THE POTENTIAL FOR LONG-TERM MONITORING AND RESEARCH OF GYRFALCON AND PEREGRINE FALCON BREEDING POPULATIONS USING UNDERGRADUATE STUDENTS: AN APPARENT INEXHAUSTIBLE SOURCE OF FUNDING
}

\author{
Robert N. Rosenfield ${ }^{1,5}$, Travis L. Booms², Kurt K. Burnham ${ }^{3}$, Brian J. McCaffery ${ }^{4}$, and \\ ROBERT J. GOODWIN ${ }^{1}$ \\ ${ }^{1}$ Department of Biology, University of Wisconsin, Stevens Point, WI 54481, USA \\ E-mail: rrosenfi@uwsp.edu \\ ${ }^{2}$ Alaska Department of Fish and Game, Wildlife Diversity Program, 1300 College Avenue, \\ Fairbanks, AK 99701, USA
}

${ }^{3}$ High Arctic Institute, 603 10th Avenue, Orion, IL 61273, USA

${ }^{4}$ US Fish and Wildlife Service, Yukon Delta National Wildlife Refuge, P.O. Box 346, Bethel, AK 99559, USA

\begin{abstract}
Climate change has caused many recent and rapid changes in the planet's ecosystems. Many of the most marked changes have occurred in the Arctic, where ecological consequences of climate change are globally underreported. Predicting and managing for future ecological consequences will likely require establishing long-term baseline and monitoring studies in a pan-Arctic network. Such studies will benefit from integration of research with education. Unfortunately, conducting field work in the Arctic is logistically difficult and securing long-term funding exacerbates this problem. Here we report a means to extend and augment baseline research on Arctic falcons with long-term funding provided by volunteer undergraduate students.
\end{abstract}

We used teams of 6 to 10 undergraduate students from the University of Wisconsin at Stevens Point to principally collect non-invasive genetic samples, and to determine occupancy and productivity at historical nest sites of Gyrfalcons (Falco rusticolus) and Peregrine Falcons (F. peregrinus) on long-term study sites on the Yukon Delta National Wildlife Refuge, Alaska, and near Kangerlussuaq, West Greenland, respectively, in four years during 2003-2010. Students received initial, on-site training, and were then responsible for conducting subsequent fieldwork. All field objectives were completed by all student groups, but some exclusive effort by experienced researchers was needed in Alaska. Students prepared a final report that detailed logistics and findings; the descriptions of logistics by students were particularly useful to future undergraduate teams. We discuss several intangibles that likely benefited students involved in these Arctic field courses.

This student research required their enrollment in ecology courses and their special course fees, totaling about $\$ 121,000$ (US dollar) for all four years, covered theirs and the senior author's travel (to, from, and within study sites), lodging, and food, but not personal camping equipment. Tech- 
nical field equipment and some logistical support were provided by collaborators. The senior author readily attracted more student applicants than could be enrolled in any of the four years of research.

We recommend the use of mentored undergraduate student coursework as a means to integrate research and education, to procure long-term funding for research and monitoring efforts of nesting Gyrfalcons and Peregrine Falcons in the Arctic, and as a means to educate future biologists about Arctic systems. Received 1 March 2011, accepted 15 April 2011.

Rosenfield, R. N., T. L. Booms, K. K. Burnham, B. J. McCaffery, and R. J. Goodwin. 2011. The Potential for long-term monitoring and research of Gyrfalcon and Peregrine Falcon breeding populations using undergraduate students: An apparent inexhaustible source of funding. Pages 373-374 in R. T. Watson, T. J. Cade, M. Fuller, G. Hunt, and E. Potapov (Eds.). Gyrfalcons and Ptarmigan in a Changing World, Volume II. The Peregrine Fund, Boise, Idaho, USA. http://dx.doi.org/10.4080/gpcw.2011.0316

Key words: Gyrfalcon, Peregrine Falcon, long-term monitoring, undergraduate students, funding, Falco rusticolus, Falco peregrinus.

Climate ChANGe Has CAUSED many recent and rapid changes in the planet's ecosystems (Heller and Zavaleta 2009). Many of the most marked changes have occurred in the Arctic where ecological consequences of climate change are globally underreported (Post et al. 2009). Arctic and sub-Arctic ecosystems harbor all Gyrfalcon and many Peregrine Falcon breeding populations (Booms et al. 2008a, Ratcliffe 1980). These ecosystems are typically regarded as relatively simple systems in which species interactions and environmentorganism dynamics are straightforward and easily understood. Recent research on the effects of climate change in these settings has however, revealed far greater ecological complexity, and the most informative studies documenting the consequences of climate change were those conducted for long enough periods of time to quantify changes from earlier baselines (Post et al. 2009). Predicting and managing for future ecological consequences for Gyrfalcons and Peregrine Falcons will thus likely in part require establishing integrated, long-term baseline and monitoring studies in a pan-arctic network (Post et al. 2009, Heller and Zavaleta 2009).
Unfortunately conducting long-term work, especially in remote areas of the Arctic and subArctic that are mostly uninhabited by humans, can be logistically difficult, if not prohibitive. This is particularly true for studying raptors, which typically nest at relatively low densities and in sites that are dangerous for researchers to access or are inaccessible to them, such as cliffs used by Gyrfalcons and Peregrine Falcons (Newton 1979, Ratcliffe 1980, Pagel and Thorstrom 2007). Exacerbating these challenges is that the greatest single problem to conducting long-term research is the difficulty of maintaining funding without interruptions (CluttonBrock and Sheldon 2010).

The practice of integrating education and other disciplines with research has been identified as a need in science, but the environmental research literature provides little documentation that such has occurred (Heller and Zavaleta 2009, Gould et al. 2010). Indeed there is an "alarming" bias toward scientists calling largely for ecological data to detect and manage for consequences of climate change; yet successful conservation will likely require integration of science with non-science disciplines and approaches for successful manage- 
ment strategies (Heller and Zavaleta 2009). Here we describe and discuss the use of undergraduate students at the University of Wisconsin at Stevens Point in field courses that involved long-term monitoring of historical nest-sites of Gyrfalcons and Peregrine Falcons in Alaska and West Greenland, respectively. We provide a detailed overview of field course activities because little such record exits, and because our experiences may be useful to others who design similar courses in Arctic settings that are physically challenging especially to inexperienced students. We highlight that special course fees of students serve as an apparently inexhaustible source of funding for the field research described herein.

\section{Study Areas ANd Methods}

The Greenland study area covers about 7000 $\mathrm{km}^{2}$ and lies in the widest part of the ice-free land in West Greenland $\left(66^{\circ} 45^{\prime} \mathrm{N}, 49^{\circ} 55^{\prime} \mathrm{W}\right)$ just north of the Arctic Circle. There is only one town, Kangerlussuaq, in this semi-mountainous tundra area with many cliffs $200 \mathrm{~m}$ in height and elevations up to $800 \mathrm{~m}$. For further descriptions of the study area, see Burnham and Mattox (1984) and Meese and Fuller (1987).

The Alaska study area covers about $700 \mathrm{~km}^{2}$ in the Ingakslugwat Hills on the Yukon Delta National Wildlife Refuge in western Alaska (61 ${ }^{\circ}$ $\mathrm{N}, 164^{\circ} \mathrm{W}$ ). Inactive volcanic craters rising up to $200 \mathrm{~m}$ above sea level dominate this sub-Arctic tundra area. See Booms et al. (2008b) for further descriptions of this site. Peregrine Falcons nest on cliffs in Greenland and Gyrfalcons are cliff-nesting raptors in both of these study areas; Peregrines have not been detected as breeding birds in the Alaska study site.

RNR (Professor of Biology and faculty of record) and TLB taught two field courses in the curriculum of the Department of Biology, College of Letters and Science, at the University of Wisconsin at Stevens Point: Arctic Ecology and Survey of Peregrine Falcons in
West Greenland, and Sub-Arctic Ecology and Survey of Gyrfalcons in Alaska. The Greenland class was four semester credits and inclusive of travel to and from the country, ran about 3 weeks during late July and early August in 2003, 2006, and 2008. The Alaska course was two semester credits and including travel to and from the state, ran about 2 weeks during late June and early July in 2010. Enrollment was limited to six or seven undergraduate students in Greenland and nine undergraduates (with another student taking the class for graduate credit) in Alaska. Students that participated were selected on various attributes, but in particular those who could document (via resume with references and an interview with RNR): good health, physical endurance, tent camping experience, enthusiasm, maturity, and good academic standing (typically students with a minimum of grade $\mathrm{B}$ average $[\mathrm{A}-\mathrm{F}$ grade scale]). Prior experience with rock climbing or nesting raptors was not required. When possible, RNR provided to students limited experience with rock climbing and/or handling of nestling and adult Cooper's Hawks (Accipiter cooperii) in Wisconsin before working in Alaska or Greenland.

Class size was principally limited by consideration of field logistics and associated safety concerns; for example, the Greenland class size reflected the number of people (eight or nine) and their gear for about 10 - 16 days of backpacking (c. 18-25 kg per heavy backpack per student for self-sustaining wilderness camping) that could safely be transferred 40 $\mathrm{km}$ one-way in one day by one or two boats down a fjord, and in Alaska by how many people (12) and their gear for 10 days of backpacking (c. 18-25 kg per heavy backpack per student for self-sustaining camping) that could safely be flown $128 \mathrm{~km}$ one-way in one day by three bush planes. Heavy backpacking occurred only on days when the classes had to move tent camps, and such occurred in more days in Greenland (5-7 days) than in Alaska (1 day, Figure 1). Light backpacks of about 5-10 $\mathrm{kg}$ were used during days when most sampling 
occurred. Each class had two instructors (RNR mentored all four classes, TLB taught once in Greenland and in Alaska) who were experienced Gyrfalcon and Peregrine Falcon researchers in these study areas, except that RNR was new to the Alaska study area. All classes were preceded with at least one group meeting in Wisconsin in which a preview of the field work and a history of the research on each study site were addressed; this meeting also provided an opportunity for students to ask questions. Students were provided with a suggested equipment/gear list about 6 months before the class began. Climbing gear such as sit-harnesses, ropes, carabiners, safety helmets, and descenders was provided by RNR and TLB, although some students brought some personal climbing gear. Use of on-site field equipment and a van stored in Kangerlussuaq, was provided by The Peregrine Fund. The vehicle provided access to some areas of the Greenland study site within c. $16 \mathrm{~km}$ of the headquarter town of Kangerlussuaq. The Alaska study site was roadless.

In Greenland students extended a study (the Greenland Peregrine Falcon Survey [GPFS]) that began in 1972 and ran 27 consecutive years, with the primary objectives of determining breeding density and reproductive performance of Peregrine Falcons. Multiple teams of two to three people were typically deployed exclusively across different parts of this large study area through 1998, the last year of the GPFS. Breeding by Gyrfalcons was incidentally and infrequently documented by the GPFS because they generally nested weeks earlier and at much lower densities than did Peregrine Falcons; Gyrfalcons rarely used the same cliffs in the same year as Peregrine Falcons in Greenland (Burnham and Mattox 1984, Mattox 2003). That said, some cliffs in the Greenland study area tended to be used only by Gyrfalcons and such sites occurred in areas surveyed by the students, who thus could have detected fledged Gyrfalcons.

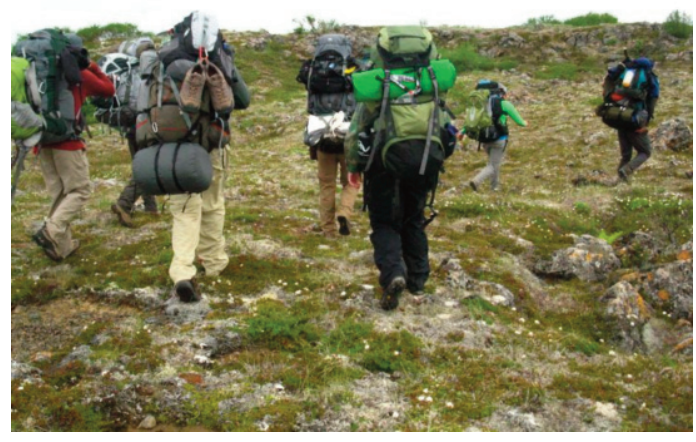

Figure 1. Heavy backpacks (18-25 kg) were used in self-sustaining wilderness camping in both Alaska (shown here) and Greenland. Foot blisters were common as a result of long (6-9 h) hikes and undergraduate students recommended durable, broken-in hiking boots, first aid supplies, and pain medication for future participants.

The Alaska study site was established in 1988 and has been investigated by one ground team (typically of two people) in consecutive years from 2003 through 2009. The primary objectives of research there is to document nest-site turnover, nest-site fidelity, and dispersal by adult and nestling Gyrfalcons through noninvasive genetic sampling of molted feathers (Booms et al. 2008b).

The course goal in both study areas was to integrate education into established research objectives in both study areas, with the caveat that research objectives would not be compromised by education activities. The instructors thus expected to get as much field work done with a class of students as they did historically without a class of students in a given number of days. After initial training by instructors at one falcon nest with young, students were responsible for virtually all field activities (except for travel arrangements), especially at nest sites (Figure 2). Field lectures and discussions that lasted from $30-60$ minutes regarding the geomorphology and the ecology of planet Earth and of the two study areas were done opportunistically, mainly at the end or the 


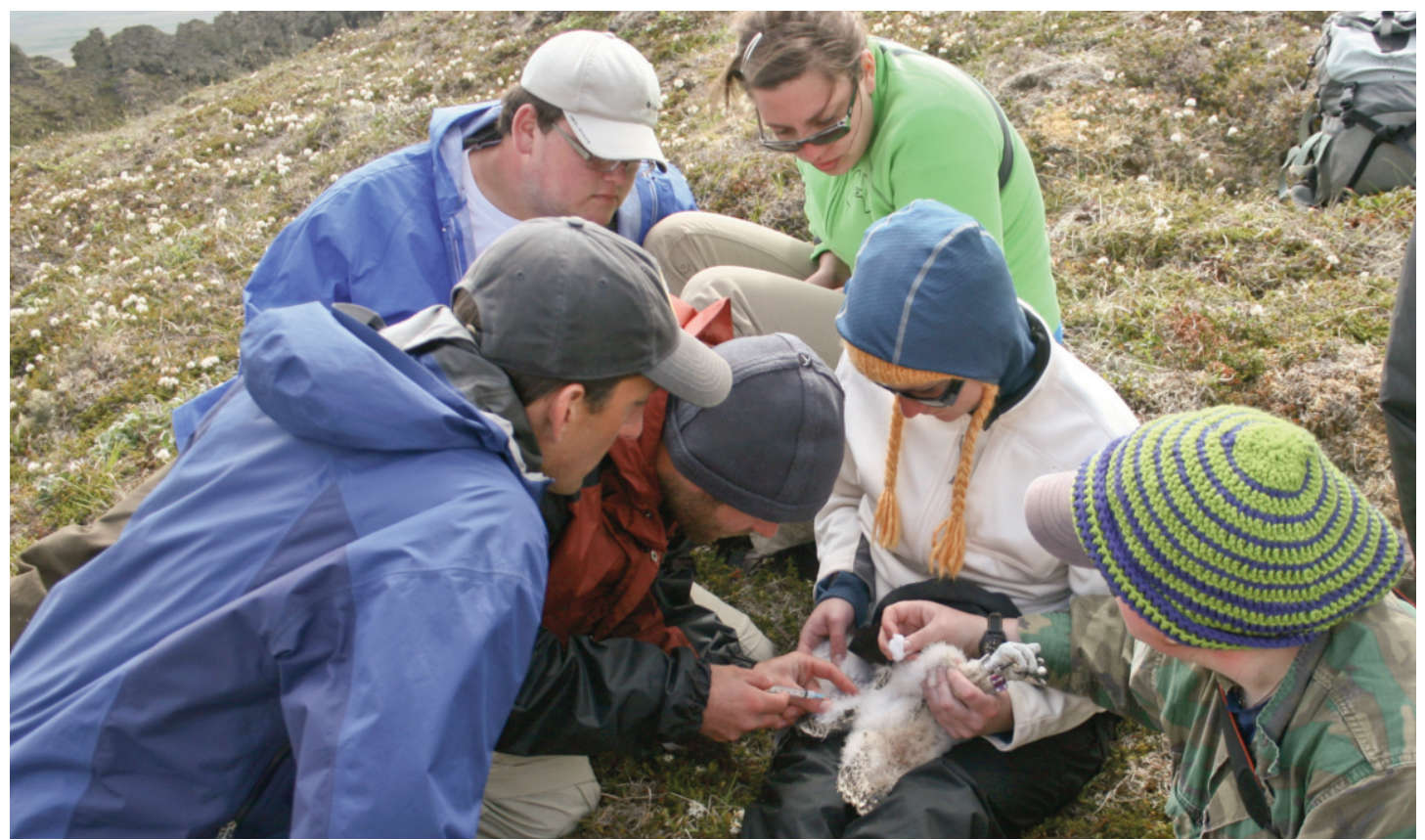

Figure 2. After initial training of undergraduate students at a nest with young, students were responsible for field activities at nest sites. Travis Booms, front left, counsels students in drawing blood from a nestling Gyrfalcon in Alaska.

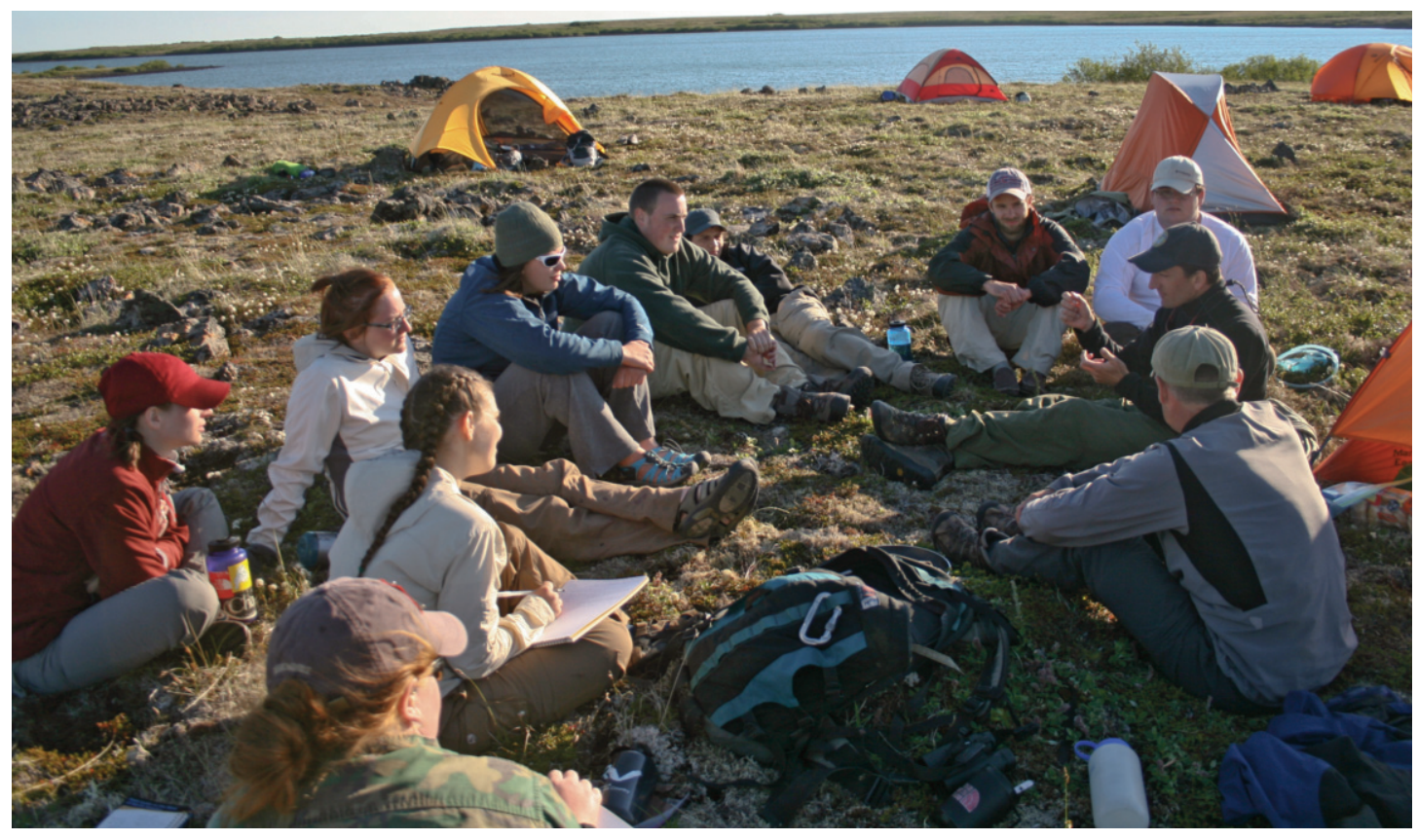

Figure 3. Scholastic-based field lectures typically occurred at the beginning and/or end of a work day. Here Travis Booms, far right, overviews the ecology of Alaska's Yukon Delta National Wildlife Refuge study area, and Gyrfalcon breeding biology. 
beginning of the day so as not to compromise the research schedule (Figure 3). We discussed science in general and the importance of tenable sampling design. We stressed safety issues of students, such as being well-hydrated and keeping a class-mate in sight when hiking, and how to traverse rocky terrain and cliffs (Figure 4). BJM, accompanied by two Alaskan Native American students, joined our class during the last several days in Alaska, and as an educational specialist with the US Fish and Wildlife Service, he provided detailed, in-depth lectures on human cultural, ecological, and conservation themes regarding the Yukon Delta National Wildlife Refuge.

A formal field report based on input from all students regarding all field charges, complemented with details of logistics and travel times in the field, and suggestions for course improvement, was written by students and presented to RNR within one month of the end of each study season. There were no exams and students earned grades (A-F) based subjectively on work ethic, enthusiasm, initiative, and an ability to engage in and foster discussions on field activities. They too were expected to participate and/or lead a discussion in the field based on pre-assigned, technical (peer-reviewed) readings on diverse topics such as climate change, biodiversity, conservation, and Gyrfalcon and Peregrine Falcon biology.

Research teams at both study areas backpacked and camped primarily as one unit on their way to and from historical cliff-sites to determine occupancy or absence of breeding birds at cliffs. In general, if a cliff site was active with nestlings that were between 2 and 3 weeks of age, and if the nest ledge could be safely reached, one student would rappel into a cliff nest, collect molted Gyrfalcon feathers at the nest ledge if in Alaska, transfer young to a backpack and ascend to the top of the cliff where students checked overall health of young, collected a blood sample from the brachial vein of each nestling, and marked

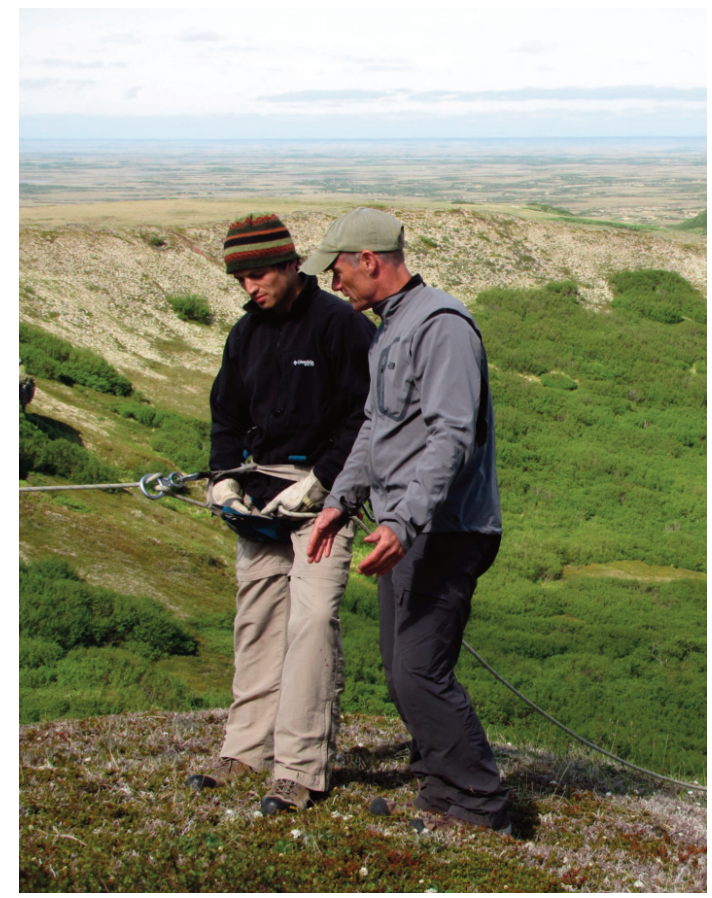

Figure 4. Safety issues were stressed with having inexperienced students perform field tasks. Here Robert Rosenfield provides instruction to a student on how to rappel into a Gyrfalcon eyrie in the Ingakslugwat Hills of the Yukon Delta National Wildlife Refuge, Alaska.

each bird with an aluminum leg band. A student then rappelled back to the nest ledge to return young. We note that searching for and collecting molted feathers of Gyrfalcons also occurred at historically used perch sites at the top of cliffs and on the ground below nest sites. All students kept detailed notes regarding field activities.

\section{Results}

Students in Greenland visited 14 total historical Peregrine Falcon cliffs in 10 days in 2003, and banded and drew blood from 18 nestlings at six of these cliffs and documented two fledged young at another cliff. They visited 18 cliffs in 16 days in 2006, and banded and drew blood from 19 young at seven of these cliffs 
and noted two fledged young at another site. In 2008 they visited 15 cliffs in 13 days and banded and drew blood from 27 young at ten of these cliffs. No nesting Gyrfalcons were detected by students in Greenland. All nests visited by students were a sub-sample of the total 125 historical cliffs used by these falcons in this study area.

Students in Alaska visited seven historical Gyrfalcon nest sites in 10 days in 2010, collected molted Gyrfalcon feathers and banded and drew blood from nine young at four cliffs. RNR and TLB exclusively collected shed feathers and banded and drew blood from three nestling Gyrfalcons at another site. All accessible historical Gyrfalcon sites on this study area were surveyed. Students also documented nesting by Rough-legged Hawks (Buteo lagopus) at seven sites, and banded six young and drew blood from five young at two nests, and Golden Eagles (Aquila chrysaetos) at another cliff where they drew blood from two nestlings.

\section{Discussion}

Our goal to integrate research with education was accomplished through our mentored field work of undergraduate students in surveys of nesting Gyrfalcons and Peregrine Falcons in Alaska and Greenland, respectively. All data collected in these classes are property of the principal investigators for each study (TLB, Alaska; KKB, Greenland), and students have not analyzed, or written up said data for publication, except that RJG was a student in the Alaska class.

Overall we believe that students performed well in these field courses for several reasons. Firstly, in all study years and on both study areas, RNR and TLB accomplished similar amounts of sampling with students in the same time (number of days) that they would have if they had been without a class. Requisite to this outcome is that students were able to hike for extended periods, often 6-9 h in both study areas where walking (even without heavy packs - see above) is exceedingly difficult and often treacherous. Indeed, excluding cliffs, terrain is uneven, rocky, often wet from dew or rain and thus slippery, and in Greenland, very hilly. That said, in Alaska two students that could not walk for one day with heavy packs because of foot blisters and physical fatigue were airlifted to another camp; and on two days, and also because of foot blisters and fatigue, no students could make two relatively long hikes (c. $20 \mathrm{~km}$ in $10 \mathrm{~h}$ and another hike c. $30 \mathrm{~km}$ in $15 \mathrm{~h}$ ) to cliff sites. In Greenland one student remained in Kangerlussuaq because he could not hike for about 7 days because of foot blisters that required medical attention; he later joined the class and engaged in all field activities.

Secondly, essentially all students performed all tasks as directed, all were tractable (especially regarding safety issues on cliffs), all students asked questions of the instructors when they were unsure about directives or did not understand the purpose of field activities, and all appeared to get along and function as a team (e.g., sharing gear and food, and providing assistance without solicitation). All seemed to freely offer their counsel when deliberations about daily activities were planned. That said, on one long hike with heavy backpack in Greenland, one student, who was last in the hiking column, became separated from the team for about $1 \mathrm{~h}$, and both instructors had to retrace the route to find the individual. The student became disoriented because hilly terrain had occluded her line of sight to the next-inline crew member.

We also believe that the success of these field courses was related to the prior research and field education provided by the two instructors. RNR had 14 previous research seasons in Greenland before the first course offering in 2003. In those years he was often accompanied by one or two individuals on their first trips to Greenland (three individuals were undergraduate students who co-published with RNR on 
Greenland research regarding both falcon species [e.g., Rosenfield et al. 1995, Taft et al . 1998]). Similarly, before he co-mentored in Greenland in 2008, TLB had 4 years of research on Gyrfalcons and Peregrine Falcons in the Greenland study area (e.g., Booms and Fuller 2003). And prior to the Alaska course, TLB had 8 previous years of research on the Alaska study site where he worked with one UWSP undergraduate in one study season (e.g., Booms et al. 2008b). Prior experience in the study sites likely resulted in a safer and more enhanced learning and research environment for the students as one or both instructors had first-hand knowledge of and had published technical papers on the ecology of the study sites, the instructor(s) knew well all travel routes and hiking times to historic cliff sites, and instructor(s) had (critically important) experience with climbing the cliffs students climbed. We did not allow any students to climb what we deemed to be very dangerous cliffs (e.g., those with many loose rocks and/or with marked overhangs); one active, overhung cliff in Greenland was inaccessible to all personnel. We also did not let students climb into nests in which we thought or knew young were too advanced in age and might prematurely jump when a researcher approached them (Rosenfield et al. 2007).

We concur with Gould et al. (2010) who, based on their Arctic field course with undergraduate students, indicated that there are several types of benefits accrued by students that are difficult to measure, including ideas, memories, and experiences that shape future decisions with potentially broad impacts (beyond themselves). To this list of benefits we add the sense of accomplishment and the likely careerenhancement of individuals whose course transcripts and resumes document novel undergraduate field research experience in Arctic settings. We also believe, as does Mattox (2003) that group experiences in Arctic wilderness settings seem to forge lasting, strong personal "bonds" among participants. This "bond," and the opportunity to provide such to other undergraduates, in part prompted TLB, who RNR took as a UWSP undergraduate student to Greenland, to render his unsolicited offer to have RNR and UWSP undergraduates join his Gyrfalcon work in Alaska. TLB is a research scientist and has no obligation to integrate his research with education. We note that despite the arduous and dangerous field activities, and the relatively large monetary expense-both in tuition, special course fees, and the purchasing of personal field equipment for this trip (see below) - students universally have indicated to us that they wouldn't have traded their Arctic experience for anything, that Greenland or Alaska "changed their lives," or that the field course was by far their best scholastic experience as an undergraduate student (Figure 5). Further testimony to these benefits is that as a consequence of interaction among student participants and their peers, RNR frequently is asked by undergraduates at UWSP when another Arctic field course is being offered so that they can plan their summer schedules accordingly should they be admitted to the class. RNR receives a greater number of applications than there are positions in these research courses.

Students must be enrolled for course credit at UWSP to participate in these field classes. The cost of enrollment included tuition and a special course fee that covered travel, lodging, and food, and such costs for RNR. The total course cost was about $\$ 3,500$ and $\$ 3,500-\$ 5,500$ (range due to inter-year variation) per student in Alaska and Greenland, respectively. Given the aforementioned class size in each of four study seasons, total funds spent by students at UWSP for these classes totaled about $\$ 121,000$ (US dollar). We suggest that there is an apparent inexhaustible source of such funds to support the field courses we describe because of the aforementioned student interest.

There are potential liabilities to including inexperienced undergraduate students in Arctic research. With more participants there is a greater risk of a physical injury occurring to 


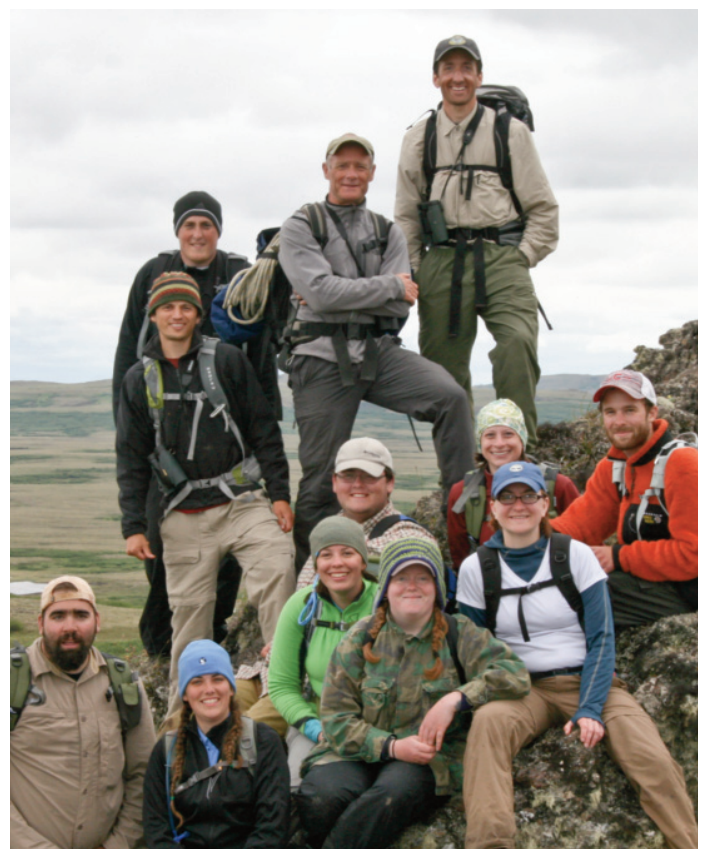

Figure 5. The 2010 team of University of Wisconsin-Stevens Point undergraduate students and their mentors (Rosenfield and Boom, top right, respectively) at a volcanic crater Gyrfalcon nest site in Alaska. These novel field courses that incorporated education with research in remote wilderness settings attracted more students than announced maximum class sizes.

any one individual during field activities. Such a situation could significantly compromise the well-being of the injured party, especially if there was a need for immediate medical attention, which essentially is not possible. Research objectives would become secondary to dealing with the care of an injured team member. We were fortunate in Alaska that the two aforementioned students who could not walk with heavy packs could be airlifted to the other tent camp as bush planes were available near our camp site on the day the team had to change tent camps. Related, we had a satellite phone in Alaska that allowed communication of our need.

It is unsurprising that physical endurance training before the field course begins is the num- ber one recommendation made by students for future participants. Students suggest hiking several hours per day for about 3 weeks in uneven terrain with a heavy backpack to simulate study area conditions. It is imperative that students wear durable hiking boots that have been broken in before the field course begins, and that they are prepared to deal with foot blisters; they should bring first aid supplies and pain killers. Students strongly recommend one or two initial days of field work without heavy backpacks so that they can "gradually" acclimate to walking Arctic terrain.

Another possible liability is that a larger number of personnel in our field courses could more likely adversely disturb breeding birds than would a smaller research team (Rosenfield et al. 2007). Our research design does not allow us to evaluate this potential effect. That said, we had no evidence from many previous years of various levels of researcher disturbance on these study areas that would suggest that our activities would negatively impact these raptors at the stage of breeding we visited nests (Rosenfield et al. 2007). We minimized the potential adverse effects of our presence by keeping visits to nests as brief as possible (typically c. 1-2 h), and by visiting cliffs during periods of no fog or precipitation, and typically during mid-day when daily temperatures were usually highest.

We re-iterate that logistics associated with class size dictated the design of the course offerings.

This did not compromise our ability to survey entirely the relatively smaller Alaska study area, but we deemed it logistically too difficult and expensive to travel to more distant locations on the much larger Greenland study area. Sampling was not random in Greenland. That said, the overall production of young per nestsite with or without nestlings documented by our field courses is similar to such historical 


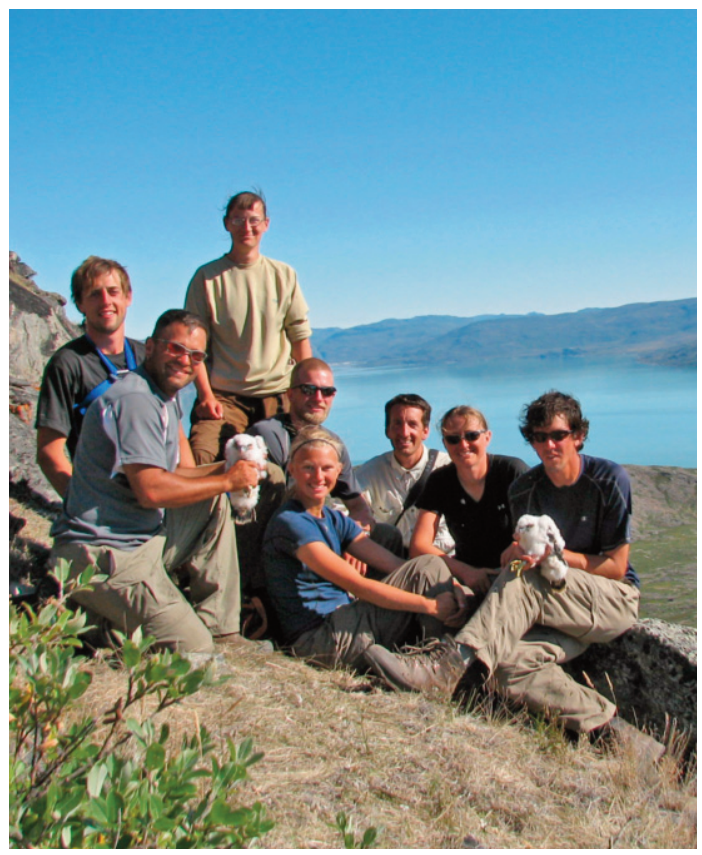

Figure 6. Funding by students through their special course fees permitted extension of a multi-decadal study of Peregrine Falcons in West Greenland. The 2008 team is pictured here.

data on each study area (RNR, TLB, KKB, and BJM, unpubl.)

We believe that the benefits of incorporating undergraduate students in research described here outweigh the risks and possible liabilities, and we recommend the use of mentored undergraduate students as a means to monitor and conduct research at historical nest sites of Gyr- falcon and Peregrine Falcon populations. We highlight that we would not have been able to extend the long-term monitoring of Peregrine Falcon sites in Greenland without the funding that students provided (Figure 6).

\section{ACKNOWLEDGMENTS}

These courses would not have been possible without the support of the Department of Biology, the College of Letters and Science, Personnel Development Committee and especially the expert staff of International Programs at the University of Wisconsin at Stevens Point. We much appreciate the support of The Peregrine Fund; the Alaska Department of Fish and Game, Wildlife Diversity Program; the US Fish and Wildlife Service, Yukon Delta National Wildlife Refuge; the High Arctic Institute; and the Greenland Home Rule Government. Many citizens of Kangerlussuaq, and the staff of the Kangerlussuaq Institute for Scientific Studies, West Greenland, assisted our classes in a variety of ways. W. G. Mattox, former director of the GPFS, provided useful counsel. J. Engum, L. Garski, C. Grasamkee, M. Koepke, M. Shaw, J. Sukow, and E. Yonke at UWSP provided excellent administrative and logistical assistance. We dedicate this paper to the memory of two inspiring falcon researchers, W. A. Burnham and H. B. Tordoff. Lastly, we commend the undergraduate students for performing well under tough field conditions. 


\section{Literature Cited}

Booms, T. L., AND M. R. Fuller. 2003. Gyrfalcon feeding behavior during the nestling period in central West Greenland. Arctic 56:341-348.

Booms, T. L., T. J. CADE, AND N. J. Clum. 2008a. Gyrfalcon (Falco rusticolus). In A. Poole (Ed.). The Birds of North America Online. Cornell Lab of Ornithology, Ithaca, New York, USA. http://dx.doi.org/ 10.2173/bna.114

Booms, T. L., B. J. MCCAFFery, AND P. S. SCHEMPF. 2008b. Molted-feather persistence and aging in a sub-arctic environment: Implications for noninvasive genetic sampling. Condor 110:756-762.

Burnham, W. A., AND W. G. Mattox. 1984. Biology of the Peregrine and Gyrfalcon in Greenland. Meddeleser om Grønland, Bioscience 14:1-28.

Clutton-Brock, T., and B. C. Sheldon. 2010. Individuals and populations: The role of long-term, individual-based studies of animals in ecology and evolutionary biology. Trends in Ecology and Evolution 25:562-573.

Gould, W. A., G. Gonzalez, D. A. Walker, AND C. L. PING. 2010. Commentary. Integrating research, education, and traditional knowledge in ecology: A case study of biocomplexity in Arctic ecosystems. Arctic, Antarctic, and Alpine Research 42:379384.

Heller, N. E., AND E. S. Zavaleta. 2009. Biodiversity management in the face of climate change: A review of 22 years of recommendations. Biological Conservation 142:1432.

Mattox, W. G. 2003. The Greenland Peregrine Falcon Survey. Pages 199-211 in T. J. Cade and W. A. Burnham (Eds.). Return of the Peregrine, a North American Saga of Tenacity and Teamwork. The Peregrine Fund, Boise, Idaho, USA.
Meese, R. J., AND M. R. Fuller. 1987. Distribution and behavior of passerines around Peregrine (Falco peregrinus) eyries in western Greenland. Ibis 131:27-32.

Newton, I. 1979. Population Ecology of Raptors. Buteo Books, Vermillion, South Dakota, USA.

Pagel, J. E., And R. K. Thorstrom. 2007. Accessing nests. Pages 171-179 in D. M. Bird and K. L. Bildstein (Eds.). Raptor Research and Management Techniques. Hancock House Publishers, Blaine, Washington, USA.

Post, E., M. C. ForchHammer, M. S. BretHarte, T. V. Callaghan, T. R. ChrisTENSEN, B. Eberling, A. D. Fox, O. Gilg, D. S. HIK, T. T. HøYE, R. A. IMS, E. JEPPESEn, D. R. Klein, J. Madsen, A. D. MCGuire, S. RYSGAARD, D. E. SCHINDLER, I. Stirling, M. P. Tamstorf, N. J. C. Tyler, R. VAN DER WAL, J. WelKer, P. A. WOOKEY, N. M. SCHMIDT, AND P. AASTRUP. 2009. Ecological dynamics across the Arctic associated with recent climate change. Science 325:1355-1358.

RatClifFe, D. 1980. The Peregrine Falcon. Buteo Books, Vermillion, South Dakota, USA.

Rosenfield, R. N., J. W. GRIER, AND R. W. FYFE. 2007. Reducing management and research disturbance. Pages 351-364 in D. M. Bird and K. L. Bildstein (Eds.). Raptor Research and Management Techniques. Hancock House Publishers, Blaine, Washington, USA.

Rosenfield, R. N., J. W. Schneider, J. M. Papp, AND W. S. SeEgar. 1995. Prey of Peregrine Falcons breeding in West Greenland. Condor 97:763-770.

TAFt, S. J., R. N. Rosenfield, W. S. Seegar, AND T. L. Maechtle. 1998. Paucity of hematozoa in Peregrine Falcons (Falco peregrinus) in West Greenland and Coastal Texas. Journal of the Helminthological Society of Washington 65:111-113. 
— Rosenfield et AL. - 